\title{
Our Consuming Problem
}

\author{
Eugene Goodheart
}

Published online: 13 March 2012

(C) Springer Science+Business Media, LLC 2012

"It's the Consumer, Stupid," reads the headline of an OP-ED in the New York Times. The argument is simple and straightforward: unless Americans reacquire their capacity to buy, buy and buy, our economy will not revive and unemployment will remain high, tragically high. According to the author of the article, James Livingston, "we consumers need to save less and spend more in the name of a better future. We don't need to silence the [industrious] ant, but we'd better start listening to the [feckless] grasshopper" (October 26, 2011). How, we might ask, are we to spend if we are in serious debt or, worse, unemployed? Don't we have to save, if we have the money to save, in order to pay off our debts? And what does Livingston propose to increase jobs and lower unemployment? He doesn't stay for answers. "Business investment, he argues, is not the key to growth," but we are not told how jobs in the private sector can be created without business investment so that more people have money to spend. He has nothing to say about government spending to stimulate the economy.

Our economy, we are told, is $70 \%$ consumer based, and many economists argue that it is unsustainable. What we need instead, they tell us, is an economy like that of Germany, driven by production and export. I am not an economist and lack the authority to participate in the debate about what is needed to "grow the economy." What is missing from the discussion, however, is a theme that has occupied social and cultural critics for decades: consumerism, which Keynes characterized as useless and wasteful consumption. It is a theme that all conscientious citizens are qualified to reflect upon. Earnest Elmo Calkins has unapologetically made the

E. Goodheart $(\bowtie)$

Department of English, Brandeis University,

Waltham, MA 02454, USA

e-mail: goodhear@brandeis.edu case for it: "consumer engineering must see to it that we use up the kind of goods we now merely use," and he goes on to say "the way to break the vicious deadlock of a low standard of living is to spend freely, and even waste creatively." Joseph Schumpeter famously characterized our economic system as "creative destruction": in less honorific terms, planned obsolescence. (The "creative" destruction of wealth is not an exclusive attribute of modern capitalism. In his classic study of The Gift in primitive societies from ancient Rome to present-day Melanesia, Marcel Mauss describes Melansia as a site of unlimited consumption and destruction. "The rich man who shows his wealth by spending recklessly is the man who wins prestige. The principles of rivalry and antagonism are basic. Political and individual status in associations and clans, and rank of every kind, are determined by the war of property, as well as by armed hostilities, by chance, inheritance, alliance and marriage. But everything is conceived as if it were a war of wealth" [35].) Of course, if our economy is inescapably consumer based, it may be counter-productive and futile at a time of crisis to lament our addiction to consumerism. If, however, our current consumer economy is unsustainable, we have an opening to think hard about the prospect of a new economy with minimal unemployment, rational consumption without a governmental command structure and with a flourishing market. Could such an economy be achieved? How can we escape wasteful and destructive consumption and maintain a decent standard of living without a command economy on the Bolshevik or Chinese model?

First, the case against consumerism: here is a summary of the 1998 UN Human Development Report Overview (figures quoted use data from 1995) as reported online by Anup Shah, "Consumption and Consumerism." "Today's consumption is undermining the environmental resource base. It is exacerbating inequalities. And the dynamic-poverty-inequality environment is accelerating. If the trends continue without change 
[and of course they have greatly accelerated since 1995]- not redistributing from high-income to low-income, consumers, not shifting from polluting to cleaner goods and production technologies, but promoting foods that empower poor producers, not shifting priority from consumption for conspicuous display to meeting basic needs-today's problems of consumption and human development will worsen" (emphasis mine). Note, the anti-consumerist argument is not an anorexic case against consumption per se, but rather an argument against what Thorstein Veblen years ago attributed to the leisure class, conspicuous consumption, which is no longer the exclusive province of the leisure class. Aroused by advertising and rivalry for the goods purchased by others, the middle class, whether or not it has the money, has conspicuously consumed on credit.

Much of the talk and political action these days is about gross inequality of wealth between one percent of the super haves and the $99 \%$ of the have-nots. A corollary of the disparity less talked about but more exigent is the inequality of consumption. According to the 1995 UN report: "Globally, the $20 \%$ of the world's people in the highest-income countries account for $86 \%$ of total private consumption expenditures - the poorest $20 \%$ a miniscule $1.3 \%$. More specifically, the richest fifth:

- Consume $45 \%$ of all meat and fish, the poorest fifth 5\%

- Consume $58 \%$ of total energy, the poorest fifth less than $4 \%$

- Have $74 \%$ of all telephone lines, the poorest fifth $1.5 \%$

- Consume $84 \%$ of all paper, the poorest fifth $1.19 \%$

- Own $8 \%$ of the world's vehicle fleet, the poorest fifth less than $1 \%$ "

The super rich have the desire and the power to buy anything they want. For them luxuries become necessities, but of course their purchasing power cannot possibly match the extent of their wealth. So billions and billions of dollars lie idle. The ambition to become rich and acquire things (luxuries as well as necessities) is the American Dream, though the purchasing power of the lower classes is often insufficient even to satisfy basic needs. What if the economy was reconceived and directed to the satisfaction of the basic needs of everyone? What would be required are policies that support a major increase in productive capacity and employment in living wage jobs. It is not as if there aren't always productive tasks to be performed. Roads, bridges and schools need to be repaired and built. The young need to be taught. An increasing population needs to be fed, clothed and housed. The unused billions in possession of the super rich would no longer lie fallow. The problem is in the structure of the economy and in the political division of views of about who and how one decides to deploy the wealth.

In the wake of the moral, political and economic collapse of Soviet-style Communism, even social democracy, an adversary of Communism, suffered guilt by association for its advocacy of a major role of government in the economy. Even many liberals in the United States whose political formation goes back to the New Deal came to share with free market conservatives a resistance to government regulation of the economy as the trajectory of economic policies from Reagan and Bush Administrations through the Clinton and Bush junior Administrations reveals. With the collapse of the Soviet Union, free market capitalism was seen as the only viable economic system, virtually above criticism. It is as if the tyranny of Communism and its fate simply cancelled out the problems of an unrestrained capitalism. "Communist" China, learning from the Soviet debacle, modified its command structure to accommodate a market economy. (For all its success in lifting millions out of poverty, state capitalism Chinese style not only represses freedom, it also generates gross economic inequality.) Given the catastrophic meltdown of our financial system and the prospect of an even more disastrous disintegration of the Eurozone, we can hardly afford the complacent confidence in deregulated market capitalism that has prevailed during the decades since the fall of the Soviet Union.

We would benefit from an earlier critique of capitalism such as R. H. Tawney's The Acquisitive Society (1920), written in a humane and democratic spirit; it has a permanent place in Mortimer Adler's Great Books series, but like most great books is confined to the academic bookshelf. Tawney saw in the unrestrained capitalism of his time what we see in our own, a culture of individual rights without social obligations. What could be more relevant to our situation than his distinction between property that is productive, useful to its owner and society, and property that is passive and merely acquisitive, for example, profits accrued from shareholding. In affirming the virtues of entrepreneurship and self-reliance, conservatives and libertarians of the right affirm "the job creators" (the active principle) at the expense of the welfare recipients (the passive principle). It is a distinction that can be directed elsewhere, as Tawney does in differentiating between both the active employer and the employed, on the one hand, and the passive shareholder, on the other. Even more relevant to our own situation is the distinction between the productive sector of the economy and the excessively remunerated financial sector, whose work is mainly the circulation of money. "The real economic cleavage," Tawney writes, "is not, as is often said, between employers and employed, but between all who do constructive work, from scientist to laborer, on the one hand, and all whose main interest is the preservation of existing property rights, upon the other, irrespective of whether they contribute to constructive work or not" (211).

A redistribution of wealth and consumption would not have to result in radical egalitarianism nor would it 
necessarily result in constraining the capacity of the rich to consume whatever they desire, but inequality would no longer be of the magnitude it is today. The wealthy would still be able to indulge their appetite for luxuries, but the unused billions of dollars could be turned to productive use and directed to places where needed. (Nor would they be prevented from bequeathing a portion of their wealth to their offspring.) The problem is not simply one of economic policy; it is about a culture that encourages the illimitable accumulation of wealth beyond need and even beyond the capacity for consuming luxury. Neither Bill Gates nor Warren Buffet nor any of their multi-billionaire or multimillionaire peers could possibly spend more than a small fraction of their wealth on everything that they desire. To be sure, they have the virtue of having put their enormous wealth to use in extraordinary philanthropy directed to deserving places, but they do not represent the majority of the super wealthy. Nor do they have either the wealth or the power to conceive and enact on a national or global scale what needs to be done. Ralph Nader in a novel, The Super Rich Will Save $U S$, suggests that an expanding cohort of the super rich would be up to the task. But again such an intervention, desirable as it is, would be insufficient.

What would be required is something on the order of a cultural revolution that would generate the moral and political will for a carefully calibrated redistribution of wealth in which government, civil institutions and individuals would be involved. It would be neither a puritan nor a Bolshevik revolution, but a humanistic one requiring us to look beyond our shores to the needs and wants of the billions of people who do not have even the basic necessities. My moderate proposal does not entail sumptuary laws that regulate the limits and character of consumption. Historically, such laws have favored the upper classes of society. Even in democratic societies, they may unintentionally favor the wealthy. The laws are also counterproductive (Prohibition being the most compelling example), since the very existence of a taboo becomes a provocation to violation rather than selfcontrol. The revolution would become a major task of our educational system. Such an education would be at once moral and aesthetic, directed to the problem of wasteful consumption.

In his memoir The Memory Chalet, published in 2010 the year of his death, Tony Judt affirms the value of austerity. "The opposite of austerity is not prosperity but luxe et volupté. We have substituted endless commerce for public purpose, and expect no higher aspirations from our leaders. Sixty years after Churchill could offer only "blood, toil, tears and sweat," our very own war president--notwithstanding the hyperventilated moralism of his rhetoric - could think of nothing more to ask of us in the wake of September 11, 2001, than to continue shopping. This impoverished view of community- 'the togetherness' of consumption - is all we deserve from those who govern us now. If we want better rulers, we must learn to ask more from them and less for ourselves. A little austerity might be in order" (32). Austerity in the public sphere is not what is needed now, given the weakness of the economy and high unemployment, but in the long run our planet with its rapidly increasing population, threatened by global warning and divided between developed, developing and undeveloped nations, euphemisms for the division between rich and poor (the divisions existing within nations as well) might benefit from Judt's counsel of austerity.

Any cultural revolution that is simply not the result of violence must seriously take into account resistance to it. The most formidable resistance has its source in libertarianism, which informs in varying degrees what I would call American ideology, mostly, though not exclusively, on the right. Libertarians not only object to a compulsory redistribution of wealth, they mistrust the very idea of government as its agent. Redistribution by government is viewed as inimical to what they value most: liberty. Libertarians mistrust "the nanny state" as encouragers of dependency. They fear the "slippery slope" that leads a welfare system to a command economy. You hear the anxiety in the warnings of the conservative George Will, who speaks again and again of 1/6th of the economy having been taken over by "Obamacare." Europeans have welfare systems much more developed than our own, and the slippery slope has proven to be illusory. Neither Sweden nor Norway nor Denmark nor Germany has a command economy nor does it have an authoritarian or totalitarian political system. The welfare system does have its drawbacks, especially when it encourages dependency. Any redistribution of wealth would have to be connected with opportunities for productive work and the willingness to work. It must support persons with disabilities who do not have the ability or capacity for work to be cared for by the state. What needs to be addressed above all is the libertarian bugaboo about redistribution of wealth. Redistribution is, of course, a fact of political life. For example, revenue collected by our federal government is sent out to the states in a manner that constitutes significant redistribution. States in need receive more than they have given, other states less than they have given. Indeed, there would be little point in having a federal government, which even libertarians believe is a minimal necessity, if such redistribution was unnecessary. Each state would tax its own citizens and the revenue would simply be used to address the needs of the state.

The left-liberal argument for redistribution is usually made on the ground of fairness. The libertarian response: is it fair to forcibly take from me what I acquire through my own initiative and hard work (or for that matter, through what I legally inherit) to benefit people I don't even know? Libertarians and conservatives tend to view any argument 
for equality or the reduction of inequality as an expression of the politics of envy and resentment. To which the pragmatic response is that an economy that allows for unchecked gross inequality simply undermines the very growth of the economy that all sides of the debate advocate by reducing the number of consumers. In an OP-ED in the NY Times (Dec. 19, 2011), two professors of law and economics, Ian Ayres and Aaron S. Edlin, recommend taxing gross inequality, not the rich. Such a policy would deflect criticism from the right that the argument for equality proceeds from envy. The rich would still be able to earn and keep a multiple of their after-tax incomes (36 times, what it is at present) significantly larger than the median American household. One may differ about the size of the multiple (I think it should be substantially lower), but the principle is clear: stem the tide of growing inequality without advocating radical egalitarianism.

Christianity, as American as libertarianism, provides a moral ground for addressing the need for redistributing wealth, Christianity. The gospels promote spiritual and moral values, above all the need to care for the poor, over material gain. Christianity has, of course, evolved from its roots in the gospels in America and elsewhere into a handmaiden to Capitalism. Max Weber described the evolution in its Calvinist manifestation: material success does not guarantee salvation, but it may contain the promise of it. If he were alive today, he might have devoted a chapter in The Protestant Ethic and the Spirit of Capitalism to the majority of American evangelicals. Evangelicals and other Christian institutions do support charitable giving, but have no real answer to the question: what if voluntary charity is insufficient? For them the "free" market comes closest to a sacred space in the secular realm, though it has hardly proven reliable in its treatment of the poor or of the increasingly impoverished middle class. Government intervention in the form of a safety net, health insurance and other benefits may not be a congenial solution to libertarians, but what then, we should ask those who are committed to Christian as well as libertarian values, are the sites that will address the problem of poverty and gross inequality when voluntary charity is insufficient? Why do the super rich need to possess billions of dollars that they can never use to satisfy even their most extravagant desires? Conspicuous display motivates the very possession of vast wealth, used or unused. There is the all-too-human gratification of pride in being listed among the wealthiest in the nation or the world in Forbes or Fortune. Contemporary Christianity for the most part seems to have averted its eyes from judging the most cardinal of sins in its own canon; in its linking of spiritual salvation to material success it has fostered pride. Pride may be an incorrigible human condition, but, as every observant Christian knows, it can and should be moderated

The seeds for change exist, if only they were recognized and cultivated. The Christian gospels apart, Americans across the political spectrum avow their patriotism, their loyalty to their fellow citizens. And yet when we go to war to defend the country they say they love, they fail to follow up the logic of their patriotism and loyalty when they resist taxation to support the war. In their devotion to sports teams, they value those players who are willing to sacrifice themselves for their team. We all admire the statistical achievements of individual stars (a conspicuous display of status hard to resist), but the players who contribute most to the success of the team are those we esteem the most. What has to become natural, instinctive, spontaneous in our political, moral and economic relationships is the spirit of cooperation that would contribute to the common good. A utopian fantasy perhaps, but the route to a new consensus (so sorely lacking in our grotesquely divided political culture) cannot be achieved solely through the conversion of ideological adversaries to the other side, it must be found in what adversaries have in common often without being aware of it. What is utopian in what I am arguing is the assumption that the adversarial differences that exist are in good faith on both sides and can be overcome through reasoning. Without good faith, the only solution (if one wants to call it that) is victory of one side over the other - a victory that at best is only provisional.

I have focused on the moral aspect of our consuming problem or, should I say, problems. What we need now are the economic policies to solve them.

\section{Further Reading}

Judt, T., 2010. The Memory Chalet. New York: Penguin Books.

Mauss, M., 1923. The Gift: Form and Function of Exchange in Archaic Societies. Trans Ian Cunnison. London: Cohen \& West LTD.

Tawney, R. H. The Acquisitive Society 1920. The Great Books of the Western World vol. 57 Social Science: Selections from Twentieth-Century Economics, Inc. Encyclopedia Britannica 1952-2005.

Veblen, Thorstein. 1899. The Theory of the Leisure Class. New York: Oxford University Press.

Eugene Goodheart is Edytha Gross Professor of Humanities Emeritus at Brandeis University. He is the author of many books of literary and cultural criticism as well as a memoir, Confessions of a Secular Jew. 